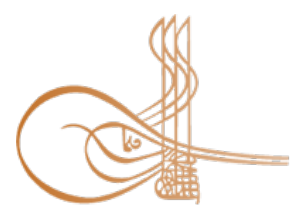

www.turkishstudies.net/social
Turkish Studies - Social Sciences

eISSN: 2667-5617

Research Article / Araștırma Makalesi

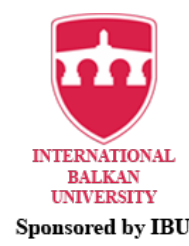

Sponsored by IBU

\title{
Ayrık Duygular Ölçeğinin Türkçeye Uyarlama, Güvenirlik ve Geçerlik Çalışması*
} Adaptation, Reliability and Validity of The Discrete Emotions Questionnaire

\author{
Tuğba Yılmaz $^{* *}$ Ece Bekaroğlu**
}

\begin{abstract}
Many studies examining human psychology try to measure emotions and relate them to other concepts. Especially in clinical psychology, emotions, thoughts, behaviors, and their relationship with psychopathology are subject to research studies. Emotions need to be conceptualized to be measured. Just as emotions are dimensionally conceptualized, there is also an approach stating that each emotion can be distinguished from each other by words, gestures and facial expressions. As a result of the approach that suggests that emotions are discrete, some measurement tools have been developed and introduced into our language. The number of separate emotions measured in these tools has been found to be limited. From this point of view, it was aimed to adapt the Discrete Emotions Scale, which was developed to measure discrete emotions, into Turkish, and to conduct validity and reliability studies. In this study, two measurements were made. In the first measurement, Positive and Negative Emotion Scale, Mood Profile and Discrete Emotion Scale were applied to 271 people. The second measurement was made by reapplying the Discrete Emotions Scale one month after the first measurement to 120 people who participated in the first measurement to measure test-retest reliability. The confirmatory factor analysis confirmed the 8-factor structure, which coincided with the original Discrete Emotion Scale. The internal consistency coefficient of the scale was 0.91 , and the testretest reliability was 0.88 . The internal consistency coefficients of the 8 sub-factors of the scale were found to be distributed between 0.72-0.91. Convergent and divergent validity of the scale was tested with the Positive and Negative Emotion Scale and the Mood Profile and significant results were obtained. The results of the study indicate that the Discrete Emotion Scale Turkish adaptation is valid and reliable.
\end{abstract}

Structured Abstract: Introduction: Considering the connection of emotions with behavior and thoughts, emotion evaluation and measurement of emotions are critical for clinical psychology. In order for emotions to be measurable, they must first be conceptualized. Two types of approaches have been adopted in determining the concept of emotion. The first one looks at the concept of emotion from a dimensional perspective (Russell, 2003; Scherer, 2005). According to this view, emotions can vary on two dimensions. These dimensions are value (valence) and arousal. Another view in the conceptualization of emotions is the view of discrete emotions (Harmon-Jones, Bastian and Harmon-Jones, 2016; Russell, 2003). According to this view, emotions do not

\footnotetext{
* Çalışmada kullanılan veriler 2020 yılı öncesine ait olup Ankara HBV Üniversitesi Etik Komisyonundan 07/03/2019-E.7769 tarih/say1lı "Uygun” raporu alınmıştır.

** Dr. Öğr. Üyesi, İzmir Bakırçay Üniversitesi, Fen Edebiyat Fakültesi, Psikoloji Bölümü

Assistant Professor, İzmir Bakırçay University, Faculty of Science and Letters Department of Psychology

ORCID 0000-0001-9187-7665

tugba.yilmaz.psy@gmail.com

*** Dr. Öğr. Üyesi, Ankara Hacı Bayram Veli Üniversitesi, Edebiyat Fakültesi, Psikoloji Bölümü

Assistant Professor, Ankara Hacı Bayram Veli University, Faculty of Letters Department of Psychology

ORCID 0000-0002-8039-9116

ecetathan@gmail.com

Cite as/ Atıf: Yılmaz, T., Bekaroğlu, E.. (2020). Ayrık Duygular Ölçeğinin Türkçeye uyarlama, güvenirlik ve geçerlik çalışması. Turkish Studies - Social, 15(4), 2233-2244. https://dx.doi.org/10.29228/TurkishStudies.40502

Received/Geliş: 10 January/Ocak 2020

Accepted/Kabul: 20 June/Haziran 2020

Checked by plagiarism software

Copyright $($ INTAC LTD, Turkey

Published/Yayın: 25 June/Haziran 2020

CC BY-NC 4.0
} 
correspond to different degrees of a dimension. Emotions have effects that can be distinguished from each other. For example, there are facial expressions or behavioral expressions specific to each discrete emotion (Ekman, 1992; Izard, 1971, 1991). When the developments in measuring emotions are analyzed, it is observed that it is preferred to conceptualize emotions dimensionally. For this reason, it is seen that a measurement tool such as Positive and Negative Emotion Scale (PANAS) that evaluates the concept of emotion based on positive and negative dimensions is preferred (Gençöz, 2000; Watson, Clark, \& Tellegen, 1988). However, there are studies that suggest that items in PANAS evaluate positive and negative emotions that arise in the event of activation (high arousal) rather than measuring positive and negative affect (eg., Watson, Wiese, Vaidya \& Tellegen, 1999). Among the measurement tools, there is Profile of mood states which has six subfactors (McNair \& Heuchert, 2003; Selvi, Güleç, Aydın \& Beşiroğlu, 2011). When this measurement tool is examined, it has more sub-scales compared to PANAS, but there is no variation in the sub-scales as positive or negative emotions. It also seems that the researchers are trying to measure emotions with a single question or a few questions, and the disadvantage of this situation is suggested to be the variance of errors that may result from the aim of measuring a structure with a small number of items (Harmon-Jones et al., 2016). In order to measure emotions under the concept of discrete emotions, this study conducted Turkish validity and reliability study of the Discrete Emotion Scale developed in English by Harmon-Jones et al. (2016).

Method: Demographic information form, PANAS, Profile of mood states and The Discrete Emotion Questionnaire were prepared and data were collected and statistically analyzed. In order to evaluate validity and reliability, the factor structure of the Discrete Emotion Scale was evaluated by confirmatory factor analysis. This analysis indicates that the original structure is valid. In addition, test-retest reliability was determined by calculating the correlation of the data obtained by applying the scale to the same people at different times. The construct validity of the discrete emotions scale was discussed by evaluating the correlations of this scale with PANAS and the Profile of mood states. It was observed that the sub-scales of the discrete emotions scale correlated with the sub-scales of PANAS and the Profile of mood states as expected. 271 people participated in the first phase of the study. 120 people participated in the second measurements made for the test-retest. The data were collected through the online data collection platform. Questionnaire items were translated into English and Turkish by bilingual clinical psychologists by using translation-translation method (Brislin, Lonner and Thorndike, 1973).

Results: The confirmatory factor analysis results and the structure of the Discrete emotions questionnaire- Turkish form have been tested to be compatible with the original model with 8 factors, each of which consists of 4 items. The internal consistency of the discrete emotions scale and test-retest reliability seem to be acceptable. The construct validity of the scale, its correlations with PANAS and the Profile of mood states were examined and evaluated, and it was seen that these relations emerged as expected.

Discussion: This study, in which the validity and reliability of the Discrete emotions questionnaire, which has not yet been adapted to another language, has been tested, shows that the validity and reliability values of this scale are acceptable and sufficient. In the original study report conducted by Harmon-Jones et al. (2016), the steps of developing the questionnaire were explained with four different studies. therefore, there may be some differences between the original work and this work. One of these differences was that the testretest reliability was not calculated in the original study; In this study, this type of reliability was evaluated. With this measurement tool, five negative and three positive discrete emotions were measured in our language. One of the features of the scale is the measurement of emotion instant or statefulness (Harmon-Jones et al., 2016). Therefore, the scale can be used in studies aiming to measure instant emotion as well as in studies aiming to measure state emotion. The 32 items of the scale consist of one word; the shortness of the items allows the scale to be used in slow reading samples. In addition, the study has a cross-sectional design, the data are collected online (online), and its sampling consists of young people and adults. The generalizability of the study is limited. It is among the suggestions that subsequent studies test the availability of Discrete emotion questionnaire in middle-advanced age samples. The usefulness, effectiveness and validity of Turkish Discrete emotion questionnaire can be tested separately with longitudinal studies.

Keywords: Clinical psychology, Emotion, Affect, Discrete emotions, Validity, Reliability.

Öz: İnsan psikolojisini inceleyen birçok araştırma duyguları ölçmeye ve başka kavramlarla ilişkilendirmeye çalışır. Özelikle klinik psikolojide duygular, düşünceler, davranışlar ve psikopatoloji ile olan ilişkisi nedeni ile 
araştırmalara konu edilmektedir. Duyguların ölçülebilmesi için kavramsallaştırılması gerekmektedir. Duyguların boyutsal olarak kavramsallaştırdığı bir yaklaşım olduğu gibi, her bir duygunun sözcükler, jest ve mimikler ile birbirinden ayrıştırılabildiğini belirten bir yaklaşım da vardır. Duyguların ayrık olduğunu öne süren yaklaşım neticesinde bazı ölçüm araçları geliştirilmiştir ve dilimize kazandırılmıştır. Bu araçlarda ölçülen ayrı duyguların sayısının kısıtlı olduğu görülmüştür. Buradan hareketle, bu çalışmada ayrık duyguların ölçülmesi amacıyla geliştirilen Ayrı Duygular Ölçeği’nin, Türkçeye uyarlanması, geçerlik ve güvenirlik çalışmalarının yapılması hedeflenmiştir. Bu çalışma kapsamında iki kez ölçüm yapılmıştır. İlk ölçümde 271 kişiye Pozitif ve Negatif Duygu Ölçeği, Duygudurum Profili ve Ayrık Duygular Ölçeği uygulanmıştır. İkinci ölçüm, test tekrar-test güvenirliği ölçmek amacıyla ilk ölçüme katılmış olan 120 kişiye ilk ölçümden bir ay sonra Ayrık Duygular Ölçeğinin tekrar uygulanması ile yapılmıştır. Doğrulayıcı faktör analizi aracılığıyla, özgün Ayrık Duygular Ölçeği ile örtüşen 8 faktörlü yapı doğrulanmıştır. Ölçeğin iç tutarlık katsayısı 0.91, test tekrar-test güvenirliği 0.88 olarak belirlenmiştir. Ölçeğin 8 alt faktörünün iç tutarlık katsayılarının 0.72-0.91 arasında dağıldığı bulunmuştur. Ölçeğin yakınsak ve ıraksak geçerliği Pozitif ve Negatif Duygu Ölçeği ve Duygudurum Profili ile test edilmiş ve anlamlı sonuçlar elde edilmiştir. Araştırmanın sonuçları Ayrık Duygular Ölçeği Türkçe uyarlamasının geçerli ve güvenilir olduğuna işaret etmektedir.

Anahtar Kelimeler: Klinik psikoloji, Duygu, Ayrık Duygular, Güvenirlik, Geçerlik.

\section{Giriş}

Çoğu insanın yaşantısında önemli bir yer tutan duygunun tanımının yapılması önce onun kavramsallaştııılmasını gerektirmektedir. Duygu kavramının belirlenmesinde iki çeşit yaklaşım benimsenmiştir. Bunlardan ilki duygu kavramına boyutsal bir bakış açısı ile bakmaktadır (Russell, 2003). Buna göre duygular iki boyut üzerinde çeşitlenmektedir. Bu boyutlardan ilki memnuniyet ve memnuniyetsizlik (pleasure-displeasure) şeklinde kutupları olan boyuttur. Bu boyuta göre örneğin 1stırap çekmek memnuniyetsizlik kutbuna yakın bir duygu iken coşkunluk memnuniyet kutbuna yakın bir duygudur. İkinci boyut ise uyarılmışlık (arousal) olarak isimlendirilmiştir. Bu boyutun kutupları etkinleşme ve etkisizleşme (activation-deactivation) şeklindedir. Bu boyut için telaşlı hissetmek etkinleşme boyutuna yakın, uyuşukluk ise etkisizleşme boyutuna yakın bir duygu olarak örneklendirilebilir (Russell, 2003). Benzer şekilde Scherer (2005) de duyguların iki boyut üzerinde değerlendirilmesi gerektiğini savunmuştur. Buna göre duygular, değer (valans; olumlu -olumsuz) ve uyarılmışlık (uyarılmışl1k-uyku hali) olmak üzere iki boyutta yer almaktadır (Lang, Greenwald, Bradley ve Hamm, 1993).

Duygunun kavramsallaştırılmasındaki diğer görüş ise ayrık duygular görüşüdür (discrete emotions; Harmon-Jones, Bastian ve Harmon-Jones, 2016; Russell, 2003). Bu görüşe göre duygular bir boyutun farklı derecelerine karşılık gelmez. Duygular birbirinden ayrıştırılabilir etkilere sahiptir. Örneğin, her bir ayrık duyguya özgü yüz ifadeleri ya da davranışsal ifadeler bulunur (Ekman, 1992; Izard, 1971, 1991). Panksepp (1998) ayrık duyguları insan ve hayvan katılımcılar üzerinde sinirbilim (nörobilim) ile incelemiş̧tir. Bu bilgileri destekleyecek şekilde Scherer (2005) duyguları ifade eden sözcüklerin birbirinden ayrı olmasının nedeni olarak, her bir sözcüğ̈̈n ayrı jest ve mimik ortaya çıkarmasını ve farklı fizyolojik tepkilere neden olmasını ileri sürmüştür. Buradan hareketle, duygular birbirinden ayrık olarak ele alındığında, çeşitli duyguların bireylerde uyandırdığı farklı deneyimlerin araştırılabilmesi mümkündür (Keltner ve Lerner, 2010).

Duyguların ölçülmesi konusundaki gelişmeler incelendiğinde ise araştırmalarda duyguların boyutsal olarak kavramsallaştırılmasının tercih edildiği gözlenmektedir (Alakuş ve Türkoğlu, 2019; Gök, Selçuk ve Gençöz, 2018; Harmon-Jones, Bastian ve Harmon-Jones, 2016). Bu nedenle araştırmalarda sıklıkla Pozitif ve Negatif Duygu Ölçeği (PANAS) gibi duygu kavramını pozitif ve negatif boyutlar üzerinden değerlendiren bir ölçüm aracının tercih edildiği görülmektedir (Gençöz, 2000; Watson, Clark ve Tellegen, 1988). Orijinal PANAS'ın hazırlanması esnasında seçilen duygu maddelerinin sadece bir faktöre yüklenmesi amaçlanmıştır (Harmon-Jones, Bastian ve HarmonJones, 2016; Watson, Clark ve Tellegen, 1988). Diğer bir deyişle, PANAS'taki pozitif duyguyu ölçen 
maddelerden her biri sadece pozitif duygu faktörüne yüklenmeli, negatif duygu faktörüne ise sıfir derecesinde yüklenmelidir. Bu durum negatif duygu maddeleri için tam tersidir. Pozitif duyguları tanımlayan maddelerde bu sebeple neşeli, mutlu gibi ifadeler yer almamaktadır. Bunun yerine, pozitif duyguları içeren maddelerde uyanık, aktif, dikkatli gibi maddeler yer almaktadır. Benzer şekilde, negatif duyguyu ölçen maddelerde üzgün, kederli, kızgın gibi maddelerden yerine tedirgin, korkmuş ve düşmanca gibi maddeler yer almaktadır. Dikkat edildiğinde pozitif duygu durumunu ölçen dikkatlilik, uyanıklık ve aktiflik sadece olumlu duygulanımlarda değil, tehlike anında olmak gibi olumsuz duygulanımlarda da hissedilebilir (Harmon-Jones ve ark., 2016).

Buradan hareketle, Watson, Wiese, Vaidya ve Tellegen (1999), PANAS'ın pozitif etkinleşme (activation) ve negatif etkinleşme ölçümü aracı olarak ele alınmasını önermişlerdir. Watson ve arkadaşlarının (1999) bu önerisi, PANAS'taki maddelerin etkinleşme (yüksek uyarılmışlık) durumunda ortaya çıkan pozitif ve negatif duygular olduğunu ortaya çıkarmıştır. Bunu destekleyecek şekilde, Harmon-Jones, Harmon-Jones, Abramson ve Peterson'un (2009) öfke ile ilgili yaptığ 1 çalışmada katılımcıların öfke duyduğunda PANAS'taki maddelerin üç faktör üzerinde yüklendiği görülmüştür. Bu çalışmada pozitif duygu maddeleri ilk faktör, öfke maddeleri ikinci faktör, korku ve kaygı maddeleri üçüncü faktör altında kümelenmiştir (Harmon-Jones ve ark., 2009). Öfke gibi değeri (valansı) negatif olan ve yaklaşma motivasyonu taşıyan bir duygunun yaşanmasında pozitif duyguların yükselmesi, araştırmacılar tarafından PANAS'taki pozitif duygu maddelerinin yaklaşım motivasyonunu ölçmeye daha duyarlı olabileceği şeklinde yorumlanmıştır (Harmon-Jones ve ark., 2009). Bu gibi nedenlerle, özbildirim yolu ile yapılacak duygu ölçümlerinde PANAS'a ek olarak başka ölçümlere de ihtiyaç duyulmaktadır.

Duygudurum profili (Profile of Mood States) özbildirim yolu ile duygu ölçen başka bir ölçme aracıdır (McNair ve Heuchert, 2003; Selvi, Güleç, Aydın ve Beşiroğlu, 2011). Duygudurum profili duygu karışımı alt ölçekleri olan bir araçtır ve altı farklı alt ölçeği vardır. Bu alt ölçekler "çökkünlükkeyifsizlik", "gerginlik-sıkıntı", "öfke-saldırganlık”, "şaşkınlık-şaşırmışlık ”, "yorgunluk-durgunluk " ve "dinçlik-aktiflik" şeklindedir. Duygudurum profili klinik amaçlarla kullanıldığı gibi araştırma amacıyla da kullanılan bir ölçektir (Harmon-Jones ve ark., 2016). Bu ölçüm aracı incelendiğinde PANAS'a kıyasla daha fazla altölçeğe sahiptir ancak altölçeklerinde olumlu ya da olumsuz duygular şeklinde bir çeşitlendirme bulunmamaktadır.

Özbildirim yolu ile duyguların ölçümünde tek madde (Gross ve Levenson, 1993) ya da birkaç madde (Yılmaz ve Bozo, 2019) ile ayrık duyguların ölçüldüğü araştırmalar da bulunmaktadır. Harmon-Jones ve arkadaşları (2016) tek madde ile katılımcıların öznel duygusal durumunun ölçülmesinin uygun olmayacağını öne sürmüşlerdir. Bu araştırmacılar katılımcıların duyguyu ölçen tek maddeyi farklı durumlarda farklı anlayabileceklerini öne sürmüştür. Birkaç madde ile duygunun ölçülmesinin uygun olmayacağını ise hata varyansının fazla olması şeklinde nedenselleştirmişlerdir (Harmon-Jones ve arkadaşları, 2016).

Ayrık duyguların ölçülmesi amacıyla hazırlanmış başka özbildirim ölçekleri de bulunmaktadır. Bu özbildirim ölçekleri ile ilgili olan durumlar ise ölçeklerin ölçmeyi hedeflediği ayrık duygu sayısının kısıtlı olması (örn, Haidt, McCauley ve Rozin, 1994, Tracy ve Robins, 2007) ve bu ölçümlerin durumluk duygu ölçümü yapmaya uygun olmaması şeklindedir (Harmon-Jones ve ark., 2016).

Ayrık Duygular Ölçeği (ADÖ), öfke, korku, kaygı, üzüntü, tiksinme gibi negatif ve rahatlama, arzu ve mutluluk gibi pozitif duygu durumlarını temel duygular kuramları (Ekman, 1992; Izard, 1971) çerçevesinde araştırmayı amaçlayan bir ölçüm aracıdır. ADÖ, orijinal adı ile Discrete Emotions Scale olarak Harmon-Jones ve arkadaşları (2016) tarafından bir seri çalışma sonucunda güvenirlik ve geçerlik çalışması yapılarak geliştirilmiştir. Bu çalışmanın amacı duygunun ayrık olarak kavramsallaştırılarak özbildirim yolu ile ölçülmesini sağlayabilecek bu ölçüm aracının Türkçe’ye kazandırılmasını sağlamaktır. 


\section{Yöntem}

\section{Katılımcilar}

Çalışmaya Ankara Gazi Üniversitesi $(\mathrm{N}=165)$ ve İzmir Bakırçay Üniversitesi $(\mathrm{N}=106)$ birinci sınıf öğrencileri olmak üzere toplamda 271 kişi katılmıştır. Öğrenciler psikoloji $(N=51)$, beslenme ve diyetetik $(\mathrm{N}=75)$ ve fizik tedavi ve rehabilitasyon bölümlerinde $(\mathrm{N}=146)$ öğrenim görmektedir. Cinsiyet dağılımı açısından katılımcılar 236 kadın (\%87) ve 33 erkekten (\%12) oluşmuştur. Katılımcılardan ikisi cinsiyetini belirtmek istememiştir. Katılımcılar 18-44 yaş arasındadır. 18 yaşında olan 61, 19 yașında olan 102, 20 yaşında olan 75,21 ve 44 yașları arasında olan 33 kişi bulunmaktadır. Sosyoekonomik olarak alt düzeyden 125, orta düzeyden 143, üst düzeyden ise 2 katılımcı yer almaktadır. Test-tekrar test geçerlik ölçümü için ilk ölçümlere katılan 120 katılımcı ikinci aşamaya gönüllü olmuş olup öğrencilerin yaş aralığı 18-44 şeklindedir. İkinci çalışmaya katılanların 98'i kadın, 22'si erkekten oluşmaktadır.

\section{Ölçüm Araçları}

Demografik Bilgi Formu. Bu form ile katılımcıların yaşları, cinsiyetleri, üniversiteleri, bölümleri, sınıfları, sosyoekonomik düzeyleri hakkında sorular sorulmuştur.

Pozitif ve Negatif Duygu Ölçeği (PANAS). PANAS toplamda 20 maddeden oluşan duyguları pozitif ve negatif olmak üzere iki ayrı boyut üzerinden değerlendiren bir ölçüm aracıdır (Watson, Clark ve Tellegen, 1988). Ölçekteki 10 madde pozitif duygu alt ölçeğine, 10 madde ise negatif duygu alt ölçeğine aittir. Ölçek 5'li Likert skalası üzerinden cevaplanmakta olup 1= "çok az veya hiç", 5= "çok fazla" anlamına gelmektedir. Alt ölçeklerden elde edilen puanların yüksek olması o türden duyguların yüksek düzeyde yaşandığına işaret etmektedir. PANAS, Türkçe'ye Gençöz (2000) tarafından geçerlik ve güvenirlik çalışması yapılarak uyarlanmıştır.

Duygudurum Profili (DP). Bu ölçüm aracı duygu karışımlarını ölçmek üzere kullanılmıştır. DP 5'li Likert skalası şeklinde cevaplanmakta olup $0=$ "asla", 4 = "aşırı" cevaplarına karşılık gelmektedir. Orijinal ölçekte 65 madde 6 alt ölçek altında yer almaktadır (McNair, Lorr ve Droppleman, 1981). Ölçeğin Türkçe uyarlamasında 7 madde [(1) arkadaşça, (6) iyimser, (13) nazik, (25) sempatik, (30) yardımsever, (43) yumuşak huylu ve (55) tevekkül eden] hiçbir alt faktöre uymaması gerekçesi ile çıkarılmıştır. Böylece DP Türkçe versiyonu 58 madde ile 6 alt ölçekte kümelenmiştir. Bu alt ölçekler "çökkünlük-keyifsizlik", "gerginlik-sıkıntı", "öfke-saldırganlık", "şaşkınlık-şaşırmışlık", "yorgunluk-durgunluk " ve "dinçlik-aktiflik" şeklindedir (Selvi, Güleç, Aydın ve Beşiroğlu, 2011).

Ayrık Duygular Ölçeği (ADÖ). Bu ölçüm aracının orijinal dili İngilizce olup Harmon-Jones ve arkadaşları (2016) tarafından geliştirilmiştir. ADÖ, 32 kısa maddeden oluşmakta ve bu maddeler 8 faktör altında toplanmaktadır. Bu alt ölçekler öfke, tiksinme, kaygı, arzu, üzüntü, korku, rahat ve mutlu şeklindedir. Her bir alt ölçek 4 maddeden oluşmaktadır. ADÖ 7'li Likert skalası üzerinden 1= "hiç katılmıyorum", 7= "aşırı derecede katılıyorum" şeklinde cevaplanmaktadır. Ölçek Türkçe’ye yazarlar tarafından çevrilmiştir.

\section{İşlem}

Discrete Emotions Scale adı ile geliștirilmiș olan bu ölçeğin sahibi Harmon-Jones ile e-posta yolu ile yazışılarak ölçeğin Türkçe'ye kazandırılması amacı ile izni alınmıştır. Çalışmanın gerçekleştirilebilmesi için Ankara Hacı Bayram Veli Üniversitesi Etik Kurulu'ndan izin alınmıştır. Çalışma soruları online ortamda (qualtrics.com) hazırlanmıştır. Soruların doldurulması ortalama 35 dakika sürmektedir. Bilgilendirilmiş onam formu çalışma soruları öncesinde, katılım sonrası bilgilendirme formu ise çalışma soruları bittikten sonra katılımcılara sunulmuştur. Katılım sağlayan öğrencilere derslerinde ekstra kredi verilmiştir. Test-tekrar test ölçümleri için öğrencilerle bir ay ara ile tekrar iletişim kurulmuştur. 
Ölçek maddeleri İngilizce ve Türkçe dillerine yetkin klinik psikologlar tarafından çevirigeriçeviri yöntemi çevrilmiştir (Brislin, Lonner ve Thorndike, 1973). İngilizce'den Türkçe'ye yapılan çeviriler karşılaştırılmış, üzerinde fikir birliği olmayan maddeler belirlenmiş ve en uygun çevirinin bulunması sağlanmıştır. Bu maddelerin hazırlanması sonrasında İngilizce ve Türkçe dilinde yetkin başka bir psikolog tarafından maddeler İngilizce'ye çevrilmiş ve orijinal maddelerle kıyaslanmıştır. İlk ölçümlere katılan 271 katılımcılan 120'si ikinci ölçümlere katılmıştır.

\section{Bulgular}

\section{Verilerin Analizi}

Bu çalışmada veriler SPSS ve JAMOVI programları aracıllı̆g ile istatistiksel analizlere tabi tutulmuştur. Ayrık Duygular Ölçeği'nin (ADÖ) faktör yapısının orijinalindeki gibi 8 faktörlü/alt ölçekli olup olmadığı doğrulayıcı faktör analizi aracılığı ile değerlendirilmiştir. Güvenirlik analizi için ilk aşama ve ikinci aşamada elde edilen veriler arasında Pearson korelasyon analizi yapılmıştır. ADÖ'nün iç tutarlılık düzeyi Cronbach's alpha katsayıları ile belirlenmiştir. ADÖ'nün yap1 geçerliğini ölçmek için bu ölçekten elde edilen veriler, Pozitif ve Negatif Duygu Ölçeği (PANAS) ve Duygudurum Profili'nden (DP) elde edilen verilerle korelasyon analizine tabi tutulmuştur.

\section{Ayrık Duygular Ölçeğinin Faktör Yapısı}

271 katılımcıdan elde edilen veriler JAMOVI programı ile doğrulayıcı faktör analizi ile değerlendirilmiştir. ADÖ verilerinin her biri 4 maddeden oluşan 8 faktörlü orijinal modeli ile uyumlu olup olmadığ 1 doğrulayıcı faktör analizi ile incelenmiştir. Sonuçlar, SB $\chi 2=1068, \mathrm{df}=436, \mathrm{p}<$ $.001, \mathrm{CFI}=.879, \mathrm{RMSEA}=.073, \mathrm{SRMR}=.063, \mathrm{TLI}=0.862$ verilerin 8 faktörlü orijinal modele uyduğunu göstermektedir. Doğrulayıcı faktör analizi sonucunda elde edilen uyum indeksleri incelendiğinde, ilk aşamadan elde edilen verilerin 8 faktörlü modele uyumu kabul edilebilir düzeydedir (Hooper, Coughlan ve Mullen, 2008). Ölçekte yer alan 32 maddenin her birinin faktör yükü .55 değerinden yüksektir ve her biri $\mathrm{p}<.001$ değerinde anlamlılık göstermiştir.

\section{Ayrık Duygular Ölçeği Alt ölçekler Arası Korelasyonlar}

ADÖ’nün öfke, tiksinme, arzu, kaygı, üzüntü, korku, rahat ve mutlu olmak üzere sekiz altölçeği arasındaki ilişkiler Tablo 1'de gösterilmiştir. Öfke alt ölçeği, rahat ve mutlu alt ölçekleri ile; tiksinme alt ölçeği, mutluluk alt ölçeği ile; arzu alt ölçeği, tiksinme alt ölçeği ile istatistiksel olarak anlamlı bir korelasyon göstermemiştir. Kayg1 alt ölçeği, rahat ve mutlu alt ölçekleri ile beklenildiği üzere negatif bir korelasyon göstermiş olsa da bu korelasyonlar istatistiksel olarak anlamlı değildir. Korku alt ölçeği, rahat ve mutlu alt ölçeği ile istatistiksel olarak anlamlı korelasyon göstermemiştir. Rahat alt ölçeği üzüntü ile, üzüntü alt ölçeği ise mutluluk alt ölçeği ile istatistiksel olarak anlamlı korelasyon göstermemiştir.

Tablo 1: Ayrık Duygular Ölçeği Alt ölçekleri Arası Korelasyonlar

\begin{tabular}{|c|c|c|c|c|c|c|c|c|}
\hline & Öfke & Tiksinme & Arzu & Kayg1 & Korku & Rahat & Üzüntü & Mutlu \\
\hline Öfke & - & & & & & & & \\
\hline Tiksinme & $.70 * *$ & - & & & & & & \\
\hline Arzu & $.27 * *$ & $.16^{* *}$ & - & & & & & \\
\hline Kayg1 & $.56^{* *}$ & $.47 * *$ & $.18^{* *}$ & - & & & & \\
\hline Korku & $.69^{* *}$ & $.67 * *$ & $.20 * *$ & $.75 * *$ & - & & & \\
\hline Rahat & .09 & $.13^{*}$ & $.47 * *$ & -.06 & .03 & - & & \\
\hline Üzüntü & $.52 * *$ & $.48 * *$ & .09 & $.54 * *$ & $.59^{* *}$ & .03 & - & \\
\hline Mutlu & .09 & .03 & $.65^{* *}$ & -.06 & .02 & $.64 * *$ & -.11 & - \\
\hline
\end{tabular}

Not. $* p<.05, * * p<.01$ 


\section{Ayrık Duygular Ölçeği Güvenirlik Göstergeleri}

ADÖ'nün test-tekrar test güvenirliği 120 kişi ile yapılan korelasyon analizi neticesinde $r=$ $.88, p<.01$ seviyesinde anlamlı şekilde bulunmuştur. Alt ölçeklerin test-tekrar test güvenirlik değerleri .81 ve .89 arasında değişmektedir ve istatistiksel olarak anlamlıdır. ADÖ’nün iç tutarlılığı Cronbach's alpha katsayıları incelenerek belirlenmiştir. Buna göre tüm ölçeğin $\alpha=.913$ iken, öfke alt ölçeği $\alpha=.879$, tiksinme alt ölçeği $\alpha=.91$, arzu $\alpha=.813$, kayg1 alt ölçeği $\alpha=.829$, üzüntü alt ölçeği $\alpha=.756$, korku alt ölçeği $\alpha=.844$, rahat alt ölçeği $\alpha=.724$ ve mutlu alt ölçeği $\alpha=.858$ şeklinde iç tutarlılık değerleri göstermiştir.

ADÖ’deki 32 maddenin ortalama, standart sapma değerleri gibi merkezi eğilim göstergeleri, düzeltilmiş madde-bütün korelasyonu ve madde silindiğindeki güvenirlik değerleri ile birlikte Tablo 2 'de gösterilmektedir. Ayrıca bu tabloda alt ölçeklerde hangi maddelerin bulunduğu bilgisi de yer almaktadır.

\section{Ayrık Duygular Ölçeği Yapı Geçerliği}

ADÖ’nün yapı geçerliğini değerlendirmek amacı ile PANAS ve DP ölçüm araçlarından faydalanılmıştır. PANAS'ın pozitif duygu (PD) ve negatif duygu (NP) olmak üzere iki alt ölçeği bulunmaktadır. DP'nin çökkünlük, gerginlik, öfke, şaşkınlık, yorgunluk ve dinçlik olmak üzere 6 alt ölçeği bulunmaktadır. ADÖ'nün tümünün ve alt ölçeklerinin, PANAS ve DP alt ölçekleri ile aralarındaki korelasyonlar Tablo 3'te göstermiştir.

ADÖ'deki negatif duyguyu ölçen öfke $(r=.34, p<.01)$, tiksinme $(r=.31, p<.01)$, kaygı $(r$ $=.34, p<.01)$, üzüntü $(r=.43, p<.01)$ ve korku $(r=.40, p<.01)$ alt ölçeklerinin PANAS'ın negatif duygu altölçeği ile pozitif ve istatistiksel olarak anlamlı sonuçlar verdiği görülmektedir. Bu alt ölçeklerden üzüntü haricindeki diğerleri PANAS'taki pozitif duygu altölçeği ile istatistiksel olarak anlamlı sonuçlar vermemiştir. Üzüntü ise PANAS'taki pozitif duygu ile negatif ve istatistiksel olarak anlamlı korelasyon gösterdiği $(r=-.17, p<.01)$ görülmektedir.

Benzer şekilde, ADÖ'deki pozitif duyguyu ölçen arzu $(r=.30, p<.01)$, rahat $(r=.27, p<$ $.01)$ ve mutlu $(r=.36, p<.01)$ alt ölçekleri, PANAS'ın pozitif duygu altölçeği ile olumlu ve istatistiksel olarak anlamlı sonuçlar vermiştir. Arzu $(r=.23, p<.01)$ haricindeki diğer alt ölçekler PANAS'taki negatif duygu ile istatistiksel olarak anlamlı korelasyon göstermemiştir.

DP’nin çökkünlük, gerginlik, öfke, şaşkınlık ve yorgunluk alt ölçekleri ile ADÖ’nün öfke, tiksinme, kayg1, üzüntü ve korku alt ölçekleri pozitif ve istatistiksel olarak anlamlı korelasyonlar göstermiştir. Bulgularda DP'nin 5 alt ölçeğinin en yüksek korelasyonları üzüntü alt ölçeği ile elde etmiş olması dikkati çekmektedir. DP'deki bu beş alt ölçeğin, negatif duygudurumu temsil ettiği göz önüne alındığında, ADÖ’deki öfke, tiksinme, kaygı, üzüntü ve korku gibi negatif duygularla olan yüksek korelasyonu anlam kazanmaktadır.

DP'deki tek pozitif duygu ölçen dinçlik-aktiflik alt ölçeğinin, ADÖ'deki pozitif duyguyu ölçen, rahat $(r=.27, p<.01)$, mutlu $(r=.37, p<.01)$ ve arzu alt ölçekleri $(r=.26, p<.01)$ ile pozitif ve istatistiksel olarak anlamlı korelasyon elde ettiği görülmektedir. Rahat ve mutlu alt ölçeklerinin DP'deki diğer beş alt ölçek ile istatistiksel olarak anlamlı korelasyonları olmazken, arzu alt ölçeğinin çökkünlük $(r=.15, p<.05)$, öfke $(r=.22, p<.01)$ ve şaşkınlık $(r=.19, p<.01)$ alt ölçekleri ile istatistiksel olarak anlamlı korelasyonları olduğu görülmüştür. 
Tablo 2: Ayrık Duygular Ölçeği Betimsel İstatistikler ve Güvenirlik Analizleri

\begin{tabular}{|c|c|c|c|c|c|}
\hline & Ortalama & $\begin{array}{l}\text { Standart } \\
\text { Sapma }\end{array}$ & $\begin{array}{l}\text { Düzeltilmiş } \\
\text { madde-bütün } \\
\text { korelasyonu }\end{array}$ & $\begin{array}{l}\text { Madde } \\
\text { silindiğinde } \alpha\end{array}$ & İç tutarlılık \\
\hline \multicolumn{6}{|l|}{ Öfke } \\
\hline 1. Öfkeli & 2.92 & 1.40 & .59 & .90 & \multirow[t]{4}{*}{.88} \\
\hline 9. Hiddetli & 2.34 & 1.37 & .65 & .90 & \\
\hline 18. Kızgin & 2.90 & 1.59 & .68 & .90 & \\
\hline 31. Sinirli & 2.89 & 1.66 & .63 & .91 & \\
\hline \multicolumn{6}{|l|}{ Tiksinme } \\
\hline 6. İ̆ğenmiş & 2.40 & 1.49 & .59 & .90 & \multirow[t]{4}{*}{.91} \\
\hline $\begin{array}{ll}11 . & \text { Midesi } \\
\text { bulanmış } & \end{array}$ & 1.95 & 1.29 & .56 & .90 & \\
\hline 20. İçi kalkmış & 2.07 & 1.39 & .65 & .90 & \\
\hline 28. Tiksinmiş & 2.11 & 1.42 & .61 & .90 & \\
\hline \multicolumn{6}{|l|}{ Arzu } \\
\hline 2. İstekli & 4.46 & 1.26 & .29 & .91 & \multirow[t]{4}{*}{.81} \\
\hline 14. Arzulu & 3.65 & 1.54 & .42 & .91 & \\
\hline 22. Tutkulu & 3.46 & 1.59 & .45 & .91 & \\
\hline 24. Can atan & 3.73 & 1.57 & .48 & .91 & \\
\hline \multicolumn{6}{|l|}{ Kaygı } \\
\hline 3. Evhamlı & 2.73 & 1.52 & .33 & .91 & \multirow[t]{4}{*}{.83} \\
\hline 12. Kaygılı & 2.97 & 1.49 & .49 & .91 & \\
\hline 15. Endişeli & 2.93 & 1.43 & .63 & .90 & \\
\hline 29. Tedirgin & 2.62 & 1.43 & .58 & .90 & \\
\hline \multicolumn{6}{|l|}{ Üzüntü } \\
\hline 4. Üzgün & 3.74 & 1.48 & .44 & .91 & \multirow[t]{4}{*}{.76} \\
\hline 10. Kederli & 3.35 & 1.54 & .38 & .91 & \\
\hline 16. Yalnız & 3.32 & 1.69 & .47 & .91 & \\
\hline 21. Kimsesiz & 2.10 & 1.41 & .39 & .91 & \\
\hline \multicolumn{6}{|l|}{ Korku } \\
\hline $\begin{array}{l}\text { 8. Dehşete } \\
\text { düşmüş }\end{array}$ & 2.65 & 1.50 & .60 & .90 & \multirow[t]{4}{*}{.84} \\
\hline 17. Korkmuş & 2.43 & 1.37 & .67 & .90 & \\
\hline 23. Paniklemiş & 2.36 & 1.42 & .58 & .90 & \\
\hline 26. Ürkmüş & 2.21 & 1.28 & .61 & .90 & \\
\hline \multicolumn{6}{|l|}{ Rahat } \\
\hline 5. Rahat & 4.17 & 1.43 & .23 & .91 & \multirow[t]{4}{*}{.72} \\
\hline 13. Sakin & 4.19 & 1.38 & .06 & .91 & \\
\hline 25. Dingin & 3.58 & 1.44 & .36 & .91 & \\
\hline 27. Gevşemiş & 3.50 & 1.45 & .39 & .91 & \\
\hline \multicolumn{6}{|l|}{ Mutlu } \\
\hline 7. Mutlu & 4.89 & 1.29 & .22 & .91 & \multirow[t]{4}{*}{.86} \\
\hline 19. Memnun & 4.25 & 1.29 & .34 & .60 & \\
\hline 30. Keyifli & 4.59 & 1.33 & .30 & .68 & \\
\hline 32. Hoşnut & 4.30 & 1.36 & .33 & .91 & \\
\hline
\end{tabular}


Tablo 3: ADÖ, PANAS ve DP Arasındaki Korelasyonlar

\begin{tabular}{|c|c|c|c|c|c|c|c|c|c|}
\hline \multicolumn{10}{|c|}{ ADÖ } \\
\hline Ölçek & ölçek & Öfke & Tiksinme & Arzu & Kayg1 & Üzüntü & Korku & Rahat & Mutlu \\
\hline Ad 1 & Ad1 & & & & & & & & \\
\hline \multirow[t]{4}{*}{ PANAS } & PD & .07 & .04 & $.30 * *$ & -.10 & $-.17 * *$ & -.05 & $.27 * *$ & $.36 * *$ \\
\hline & ND & $.34 * *$ & $.31 * *$ & $.23 * *$ & $.34 * *$ & $.43 * *$ & $.40 * *$ & -.10 & -.05 \\
\hline & Çökkünlük & $.21 * *$ & $.27 * *$ & $.15^{*}$ & $.35 * *$ & $.55 * *$ & $.35 * *$ & .05 & -.04 \\
\hline & Gerginlik & $.20 * *$ & $.18 * *$ & .10 & $.37 * *$ & $.43 * *$ & $.31 * *$ & -.11 & -.11 \\
\hline \multirow[t]{4}{*}{ DP } & Öfke & $.28 * *$ & $.32 * *$ & $.22 * *$ & $.32 * *$ & $.50 * *$ & $.32 * *$ & .04 & .00 \\
\hline & Şaşkınlık & $.13^{*}$ & $.20 * *$ & $.19 * *$ & $.22 * *$ & $.25 * *$ & $.19 * *$ & .05 & .00 \\
\hline & Yorgunluk & $.23 * *$ & $.21 * *$ & .07 & $.35 * *$ & $.48 * *$ & $.30 * *$ & -.02 & -.11 \\
\hline & Dinçlik & .03 & .03 & $.26 * *$ & -.09 & -.10 & -.03 & $.28 * *$ & $.37 * *$ \\
\hline
\end{tabular}

Not 1. ADÖ= Ayrk Duygular Ölçeği, PANAS= Pozitif ve Negatif Duygular Ölçeği, DP= Duygudurum Profili

Not $2 * p<.05, * * p<.01$

\section{Tartışma}

Duygu ölçümü yapılabilmesi, klinik araştırmalarda duygular ve duygu ile ilişkili faktörlerin çalışılabilmesi için önem taşımaktadır. Ölçümünün yapılabilmesi için duygunun tanımlanması gerekmektedir. Üzerinde fikir birliği bulunan bir duygu tanımı bulunmadığı için duygu kuramları çerçevesinde hazırlanmış ölçüm araçları bulunmaktadır. Duyguların boyutsal ya da ayrık olarak ele alındığı alanyazın ışığında özbildirim yolu ile ölçüm yapan araçların sayısı yetersiz görünmektedir (Harmon-Jones ve ark., 2016).

Klinik amaçlarla da sıklıkla duygu ölçümü için kullanılan aracın PANAS (Gençöz, 2000; Watson, Clark ve Tellegen, 1988) olduğu bilinmektedir. Duyguları boyutsal olarak değerlendiren görüşe dayanarak hazırlanmış olan PANAS'ın duygu ölçmekten öte duygusal etkinleşme (activation) ölçümü yaptığına dair görüşler de yer almaktadır (Watson ve ark., 1999). Duyguların ayrık olarak ele alınabilmesi ve bunun ölçümünün birkaç maddeden daha fazlası ile yapılması amacı ile ortaya çıkan Ayrık Duygular Ölçeği (ADÖ) beşi negatif üçü pozitif duyguyu ölçen bir araçtır (HarmonJones ve ark., 2016). Bu ölçüm aracının Türkçe'ye kazandırılması için yapılan bu geçerlik ve güvenirlik çalışmasında, ölçek orijinal dili olan İngilizce'den çeviri ve geri çeviri yöntemi ile dilimize kazandırılmıştır (Brislin ve ark., 1973).

Alanyazında yapılan incelemede henüz ADÖ’nün başka dillere adapte edildiği bir çalışmaya rastlanmamıştır. Yazarların bilgisine göre, bu çalışmayla ilk kez ADÖ başka bir dile adapte edilmiş, güvenirlik ve geçerlik değerleri araştırılmıştır. Bu çalışmanın başka bir özelliği, ADÖ’nün kültürlerarası olarak geçerli bir yapısının olup olmadığını değerlendirilmesine hizmet etmesidir. Her ne kadar klinik psikoloji alanındaki çalışmalarda sıklıkla duygu ölçümü boyutsal duygu bakış açısı ile PANAS kullanılarak yapılmış görünse de (Alakuş ve Türkoğlu, 2019; Aydın, Araz ve Asan, 2011; Gök, Selçuk ve Gençöz, 2018; Karaırmak ve Siviş-Çetinkaya, 2011); duyguların kavramsallaştııılmasında ayrık duygular bakış açısından çalışma yapmak isteyen araştırmacılar sayıca az madde ile duygu ölçümü yapmaktansa (Aydın, Araz ve Asan, 2011; Y1lmaz ve Bozo, 2019) ADÖ ile sekiz farklı ayrık duygu hakkında bilgi edinebilir.

$\mathrm{Bu}$ ölçeğin Türkçe halinin orijinalindeki (Harmon-Jones ve ark., 2016) gibi 8 faktörlü bir yapıya sahip olup olmadığı doğrulayıcı faktör analizi aracılı̆̆ ile test edilmiştir. Elde edilen verilerin önerilen modele olan uygunluğunu gösteren uyum indeksleri iyi düzeyde değerler vermiştir (Hooper, Coughlan ve Mullen, 2008). Doğrulayıcı faktör analizi sonuçlarına dayanarak Türkçe ADÖ'nün 8 faktörlü bir yapıda olduğu söylenebilir.

ADÖ alt ölçekleri arasındaki ilişkiler incelendiğinde bazı alt ölçeklerin diğer alt ölçeklerle istatistiksel olarak anlamlı korelasyon göstermediği görülmektedir. Öfke, korku ve kayg1; rahat ve 
mutlu alt ölçekleri ile anlamlı korelasyon göstermezken; üzüntü ve tiksinme sadece mutlu alt ölçeği ile; arzu ve rahat alt ölçekleri ise üzüntü alt ölçeği ile anlamlı korelasyon göstermemiştir. Bu durum beklendiği üzere pozitif duyguların negatif duygulardan ayrıştığına işaret etmektedir. Böylece, araştırmanın sonuçları bu alt ölçekler için ıraksak geçerlik göstergesi olabilir. Ayrıca tiksinmenin; öfke, kaygı ve korkudan ayrı bir duygu olduğu da bu bulgulardan çıkarılabilir. Orijinal çalışmada alt ölçekler arasındaki korelasyonlar hesaplanmamıştır (Harmon-Jones ve ark., 2016).

Güvenirlik analizleri incelendiğinde ADÖ’nün alt ölçeklerinin .81 ve .88 arasında değişen test-tekrar test güvenirlik sonuçlarının iyi düzeyde olduğu görülmektedir. Orijinal çalışmada testtekrar test güvenirlik değerlendirmesi yapılmamıştır (Harmon-Jones ve ark., 2016). İç tutarlılık değerleri açısından incelendiğinde alt ölçeklerin .72 ve .91 değerleri arasında $\alpha$ değerlerine sahip olduğu görülmüştür. Orijinal çalışmada alt ölçeklerin iç tutarlılık değerleri incelenmiştir ve bu değerlerin .82 ve .96 arasında değiştiği görülmektedir (Harmon-Jones ve ark., 2016). Türkçe ölçekte en düşük iç tutarlılık .72 ile rahat alt ölçeğindeyken, bunu .75 ile üzüntü alt ölçeği takip etmektedir. Orijinal çalışmada ise en düşük iç tutarlılık .82 ile üzüntü alt ölçeğindedir. Her ne kadar orijinal çalışmada rahat alt ölçeğinin iç tutarlılığı düşük değilse de üzüntü alt ölçeği için durum hem bu çalışmada hem de orijinal çalışmada benzer görünmektedir.

Ölçeğin yapı geçerliği PANAS ve DP ve alt ölçekleri ile aralarındaki korelasyon değerleri ile incelenmiştir. Genel itibari ile bakıldığında ADÖ'deki negatif duygu alt ölçeklerinin PANAS'taki negatif duygu; ADÖ'deki pozitif duygu alt ölçeklerinin PANAS'taki pozitif duygu ile ilişkili olduğu görülmektedir. Bu durum ADÖ’nün yakınsak geçerliğine işaret etmektedir.

Öfke, tiksinme, kaygı ve korku alt ölçekleri, PANAS'taki pozitif duygu alt ölçeği ile istatistiksel olarak anlamlı korelasyon göstermemiştir. Olumsuz duygu ölçen üzüntü ise PANAS'taki pozitif duygu ile negatif ve anlamlı bir korelasyon göstermiştir. Bu durum hem üzüntünün yapı olarak diğer negatif duygulardan ayrı olduğunu gösterirken, hem de üzüntünün daha düşük pozitif duygulanımla ilişkili olduğuna işaret etmektedir.

Rahat ve mutlu alt ölçekleri beklendiği gibi PANAS'taki pozitif duygu ile anlamlı ve pozitif korelasyon göstermiş ve eşzamanlı olarak PANAS'taki negatif duygu ile anlamlı korelasyon göstermemiştir. Arzu ise PANAS'taki hem negatif hem de pozitif duygu ile anlamlı ve pozitif korelasyon göstermiştir. Bu durum arzunun duygu değeri (valansı) dolayısı ile ortaya çıkmış olabilir. Pozitif bir duygu olan arzunun tıpkı negatif bir duygu olan öfkedeki gibi duygu değeri (valansı) bu duyguyu hisseden kişilerin arzu/öfke duyduğu nesneye yaklaşmasını sağlar. Bu nedenle arzunun, negatif duygu ile anlamlı ve pozitif korelasyon gösterdiği düşünülmüştür.

ADÖ ve DP arasındaki ilişkiler incelendiğinde DP'nin çökkünlük, gerginlik, öfke, şaşkınlık ve yorgunluk alt ölçekleri ile ADÖ'deki negatif duyguları ölçen beş alt ölçeğin anlamlı ve pozitif korelasyon gösterdiği görülmektedir. Beklendiği üzere ADÖ'deki negatif duyguları ölçen beş alt ölçek, DP'deki dinçlik alt ölçeği ile anlamlı korelasyon göstermemektedir. Bu sonuçlar öfke, tiksinme, kaygı, üzüntü ve kaygının hem yakınsak hem de ıraksak geçerliğine işaret etmektedir.

Benzer şekilde, DP'deki tek pozitif duygu ölçen dinçlik-aktiflik alt ölçeğinin, ADÖ'deki pozitif duyguyu ölçen üç alt ölçekle pozitif ve istatistiksel olarak anlamlı korelasyon elde ettiği görülmektedir. Bu sonuç arzu, rahat ve mutlu alt ölçeklerinin yakınsak geçerliğini göstermektedir. Ayrıca, rahat ve mutlu alt ölçeklerinin DP'deki negatif duygu ölçen diğer beş alt ölçeği ile anlamlı ilişki göstermemesi, rahat ve mutlu alt ölçeklerinin rraksal geçerliğine işaret etmektedir. ADÖ'deki arzu alt ölçeği, çökkünlük, öfke ve şaşkınlık ile pozitif ve anlamlı ilişki göstermiştir. Arzunun, öfke ve şaşkınlık gibi yakınlık duygu değeri (valansı) gösteren duygularla pozitif ilişki göstermesi anlaş1labilir görülmektedir. Ancak arzunun çökkünlük-keyifsizlik alt ölçeği ile pozitif anlamlı ilişki göstermesi dikkati çekmektedir. Bu sonuç çökkünlük yani depresyonun arzu ile olan ilişkisinin incelenmesi doğrultusunda anlamlandırılabilir. Giesler, Josephs ve Swann (1996) depresif kişilerle yaptıkları çalışmada bu kişilerin kendilerine dair olumsuz değerlerlendirme arzusunun yüksek 
olduğunu göstermiş̧ir. Diğer bir deyişle, depresyonu fazla olan katılımcılar, az olan katılımcılara kıyasla daha fazla olumsuz değerlendirmeye açık iken olumlu değerlendirmeye karşı ise isteksiz bulunmuştur. Bu sonuca paralel olarak, Burger (1984) ise çalışmasında depresif katılımcıların hayatlarını kontrol etme arzusunun yüksek olduğu bulgusunu elde etmiştir. Diğer bir deyişle, depresyonu fazla olan katılımcılar diğerlerine göre daha fazla kontrol etme arzusu hissettiklerini rapor etmiştir. $\mathrm{Bu}$ iki çalışmadan hareketle, arzu ve çökkünlük/depresyon arasında pozitif bir korelasyon çıkmış olabilir.

$\mathrm{Bu}$ çalışmanın sonucunda elde edilen analiz sonuçlarına bakıldığında ADÖ’nün Türkçe halinin geçerli ve güvenilir olduğu söylenebilir. Bu ölçme aracı ile beşi negatif üçü pozitif ayrık duygunun dilimizde ölçülmesi sağlanmıştır. Ölçeğin özelliklerinden biri, duygu ölçümünü anlık ya da durumluk ölçmesidir (Harmon-Jones ve ark., 2016). Bu nedenle ölçek anlık duygu ölçmeyi amaçlayan çalışmalarda kullanılabileceği gibi durumluk duygu ölçmeyi amaçlayan çalışmalarda da kullanılabilir. Ölçeğin 32 maddesi birer kelimeden oluşmaktadır; maddelerin kısa oluşu ölçeğin okuma hızı yavaş örneklemlerde de kullanılmasına olanak sağlamaktadır.

Çalışmanın kesitsel bir tasarımı olması, verilerin online (çevrimiçi) ortamda toplanması ve örnekleminin genç ve yetişkinlerden oluşması sebebi bazı sınırlılıkları mevcuttur. Çalışmanın genellenebilirliği sınırlıdır. Sonraki çalışmaların orta-ileri yaş örneklemlerinde ADÖ’nün kullanılabilirliğini test etmeleri öneriler arasındadır. Boylamsal çalışmalarla Türkçe ADÖ’nün kullanışlılığı, etkililiği ve geçerliliği ayrıca test edilebilir.

\section{Kaynakça}

Alakuş, T. B., ve Türkoğlu, İ. (2019). Pozitif ve negatif duyguların ayrımında etkili eeg kanallarının dalgacık dönüşümü ve destek vektör makineleri ile belirlenmesi. Bilişim Teknolojileri Dergisi, 12(3), 229-237.

Aydın, A., Araz, A., ve Asan, A. A. (2011). Görsel Analog Ölçeği ve Duygu Kafesi: Kültürümüze Uyarlama Çalışması. Türk Psikolojileri Yazıları, 14(27), 1-13.

Brislin, R. W., Lonner, W. J., ve Thorndike, R. M. (1973). Cross-cultural research methods: Comparative studies in behavioral science. A Wiley-Intersection Publication.

Burger, J. M. (1984). Desire for control, locus of control, and proneness to depression. Journal of Personality, 52(1), 71-89. https://doi.org/10.1111/j.1467-6494.1984.tb00551.x

Ekman, P. (1992). An argument for basic emotions. Cognition \& Emotion, 6(3-4), 169-200. https://doi.org/10.1080/02699939208411068

Gençöz, T. (2000). Pozitif ve negatif duygu ölçeği: Geçerlik ve güvenirlik çalışması. Türk Psikoloji Dergisi, 15(46), 19-26.

Giesler, R. B., Josephs, R. A., ve Swann Jr, W. B. (1996). Self-verification in clinical depression: The desire for negative evaluation. Journal of Abnormal Psychology, 105(3), 358-368. doi: 10.1037//0021-843x.105.3.358.

Gök, A. C., Selçuk, E., ve Gençöz, T. (2018). Olumlu ve Olumsuz Duygulanımın Tekrarlanan Ölçümlerde Kişi-İçi Güvenirliği. Türk Psikoloji Dergisi, 33(82), 53-66. DOI: 10.31828/tpd.13004433.2018.82.02.04

Gross, J. J., ve Levenson, R. W. (1993). Emotional suppression: physiology, self-report, and expressive behavior. Journal of Personality and Social Psychology, 64(6), 970-986. https://doi.org/10.1037/0022-3514.64.6.970 
Harmon-Jones, C., Bastian, B. ve Harmon-Jones, E. (2016). The Discrete Emotions Questionnaire: A New Tool for Measuring State Self-Reported Emotions. PLoS ONE, 11(8): e0159915. doi:10.1371/journal.pone.0159915

Harmon-Jones, E., Harmon-Jones, C., Abramson, L., ve Peterson, C. K. (2009). PANAS positive activation is associated with anger. Emotion, 9(2), 183-196. https://doi.org/10.1037/a0014959

Hooper, D., Coughlan, J., \& Mullen, M. R. (2008). Structural equation modelling: Guidelines for determining model fit. Electronic Journal of Business Research Methods, 6(1), 53-60. D: 10.21427/D7CF7R

Izard, C. E. (1971). The face of emotion. Appleton-Century-Crofts.

Izard, C. E. (1991). The psychology of emotions. Plenum Press.

Karairmak, Ö., ve Çetinkaya, R. S. (2011). The effect of self-esteem and locus of control on resilience: The mediating role of affects. Türk Psikolojik Danışma ve Rehberlik Dergisi, 4(35), 30-41. doi: 0.17066/pdrd.81376

Keltner, D., Lerner, J. S. (2009). Emotion. S. Fiske, D. Gilbert (Ed.) The Handbook of Social Psychology içinde (s. 317-352). Random House.

Lang, P. J., Greenwald, M. K., Bradley, M. M., \& Hamm, A. O. (1993). Looking at pictures: Affective, facial, visceral, and behavioral reactions. Psychophysiology, 30(3), 261-273. https://doi.org/10.1111/j.1469-8986.1993.tb03352.x

McNair, D. M. ve Heuchert, J. W. P. (2003). Profile of Mood States (POMS): Technical update. First ed. Multi-Health Systems Incorporated.

Panksepp, J. (1998). Affective neuroscience: The foundations of human and animal emotions. Oxford University Press.

Russell, J. A. (2003). Core affect and the psychological construction of emotion. Psychological Review, 110(1), 145. doi: 10.1037/0033-295x.110.1.145

Scherer, K. R. (2005). What are emotions? And how can they be measured? Social Science Information, 44(4), 695-729. https://doi.org/10.1177/0539018405058216

Selvi, Y., Gulec, M., Aydin, A., ve Besiroglu, L. (2011). Psychometric evaluation of the Turkish language version of the Profile of Mood States (POMS). Psychiatry and Behavioral Sciences, 1(4), 152. doi: 10.5455/jmood.20110902072033

Tracy, J. L., ve Robins, R. W. (2007). The psychological structure of pride: A tale of two facets. Journal of Personality and Social Psychology, 92(3), 506. doi: 10.1037/0022-3514.92.3.506

Watson, D., Clark, L. A., ve Tellegen, A. (1988). Development and validation of brief measures of positive and negative affect: the PANAS scales. Journal of Personality and Social Psychology, 54(6), 1063-1070. https://doi.org/10.1037/0022-3514.54.6.1063

Watson, D., Wiese, D., Vaidya, J., ve Tellegen, A. (1999). The two general activation systems of affect: Structural findings, evolutionary considerations, and psychobiological evidence. Journal of Personality and Social Psychology, 76(5), 820-838. doi: 10.1037/00223514.76.5.820

Y1lmaz, T. ve Bozo, Ö. (2019). An experimental study about women's self-objectification, body shame, negative mood, and body dissatisfaction. Mediterranean Journal of Clinical Psychology, 7(2), 1-23. doi:10.6092/2282-1619/2019.7.2108 